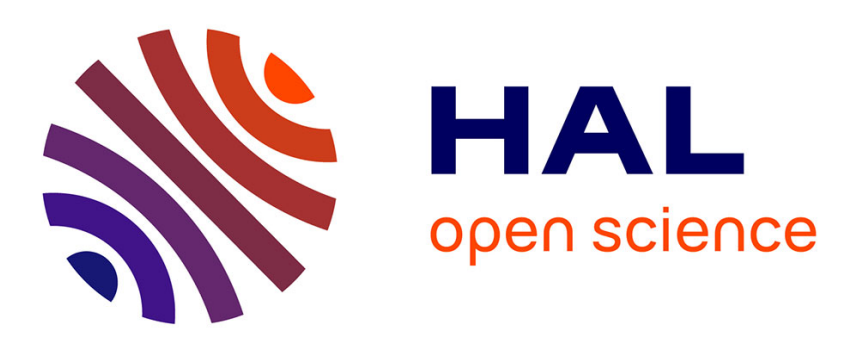

\title{
Contrasting behavior of gas and aerosol scavenging in convective rain: a numerical and experimental study in the African equatorial forest
}

\author{
S. Cautenet, B. Lefeivre
}

\section{- To cite this version:}

S. Cautenet, B. Lefeivre. Contrasting behavior of gas and aerosol scavenging in convective rain : a numerical and experimental study in the African equatorial forest. Journal of Geophysical Research, 1994. hal-01990604

\author{
HAL Id: hal-01990604 \\ https://hal.uca.fr/hal-01990604
}

Submitted on 3 Feb 2021

HAL is a multi-disciplinary open access archive for the deposit and dissemination of scientific research documents, whether they are published or not. The documents may come from teaching and research institutions in France or abroad, or from public or private research centers.
L'archive ouverte pluridisciplinaire HAL, est destinée au dépôt et à la diffusion de documents scientifiques de niveau recherche, publiés ou non, émanant des établissements d'enseignement et de recherche français ou étrangers, des laboratoires publics ou privés. 


\title{
Contrasting behavior of gas and aerosol scavenging in convective rain: A numerical and experimental study in the African equatorial forest
}

\author{
S. Cautenet
}

LAMP/Centre National de la Recherche Scientifique/URA 267, Université Blaise Pașcal, Clermont, France

\section{B. Lefeivre}

CRA/Centre National de la Recherche Scientifique/URA 354, Lannemezan, France

\begin{abstract}
A two-dimensional convective cloud model has been coupled with a chemical model consisting of the explicit prediction of five chemical species: $\mathrm{SO}_{2}$, $\mathrm{SO}_{4}^{2-}, \mathrm{NH}_{4}^{+}, \mathrm{O}_{3}$, and $\mathrm{H}_{2} \mathrm{O}_{2}$. The model takes the scavenging processes into account. We examine the relationship between the liquid water content (LWC) and the chemical concentrations of atmospheric trace elements in convective precipitation. The model results compare favorably with observations (ABLE 2B and DECAFE experiments). The modeled dilution curves were found to be nonlinear, in agreement with the DECAFE data. The model also accounts for the large differences in dilution effects that exist between gases and aerosols. More generally, this study shows that within the African equatorial forest there are (1) a reduction of aerosol scavenging efficiency with increasing rain intensity (or $\mathrm{LWCg}$ ); (2) a strong impact of vertical profiles of atmospheric trace elements on ground rain concentrations; (3) a difference in scavenging efficiencies according to the origin of the elements (gas or aerosol); and (4) a depletion of atmospheric concentrations during rainfall.
\end{abstract}

\section{Introduction}

Air pollutants are ultimately removed from the atmosphere by wet and dry depositions. The wet deposition, that is, absorption into droplets followed by droplet removal during precipitation, is the purpose of this study. The rainout scavenging efficiency depends on many processes. For aerosols, they are mainly nucleation, Brownian diffusion, and impaction. For gases, they are absorption represented by Henry's Law, ionization, if it occurs, and chemical reactions in aqueous phase. The chemical composition of ground precipitation is the final result of the scavenging of atmospheric gases and particles by both cloud droplets (rainout) and rainfall (washout), with differences in collection efficiency determined by the phase of the removed species (gas or aerosol) and by the incloud and subcloud chemical, dynamical, and microphysical processes [Flossman et al., 1987; Tremblay, 1987]. Lacaux et al. [1992a] have shown that the chemical composition of rain at ground surface strongly depends on the precipitation type.

The liquid water content is one of the important input parameters of a cloud chemistry [Chameides and Davis, 1982]. Pandis and Seinfeld [1989] have shown that an increase in liquid water content (LWC) results in a decrease of sulfate concentration in rain, but, nevertheless, to an increase of the removed total sulfate. For this reason, we particularly focused on the relation between the ionic concentration of chemical species analyzed in precipitation and

Copyright 1994 by the American Geophysical Union.

Paper number 93JD02712.

0148-0227/94/93JD-02712\$05.00 the ground mean weighted liquid water content $\overline{\mathrm{LWC}}$ (see section 4 for complete definition).

Recently, data from the Dynamique et Chimie Atmospherique en Forêt Equatoriale (DECAFE) program [Fontan et al., 1992], and a collection of granulometric spectra recordings of precipitation from June 1988 to June 1989 in the equatorial forest of North Congo (Enyelé, $2^{\circ} 5 \mathrm{~N} ; 18^{\circ} 0 \mathrm{E}$ ) led to the characterization of the physical (intensity $R, L W C$, number concentrations, and median volume diameter of raindrops) and chemical (12 chemical species analyzed) features of 67 rain events [Lefeivre, 1993]. A linear relationship was found between the species $A$ concentration and $\overline{\mathrm{LWC}} \mathrm{g}$ in convective rains $\left(\overline{\mathrm{LWC}}_{\mathrm{g}}>\mathbf{0 . 4 5 \mathrm { g } \mathrm { m } ^ { - 3 } )}\right.$ during the wet season for most chemical species:

$$
[A]_{\text {rain }}=a \overline{\mathrm{LWC}}_{\mathrm{g}}^{-1}+b
$$

There are significant differences in the coefficients $a$ and $b$ according to the origin of the compounds, either gas (e.g., $\mathrm{NH}_{3}$ ) or aerosol (e.g., $\mathrm{Mg}^{2+}$ ). The highly soluble species exhibit the larger correlation coefficients. On the other hand, for the same original phase, the values of $a$ and $b$ differ very weakly, regardless of the chemical species.

For estimating the removal of an atmospheric chemical species $A$ by the cloud droplets (rainout), the following relationship is often used:

$$
[A]_{\text {rain }}=\varepsilon[A]_{\mathrm{air}} \mathrm{LWC}^{-1} \text {, }
$$

where $[A]_{\text {air }}$ is the chemical content of species $A$ in air ( $\mu \mathrm{g}$ $\mathrm{m}^{-3}$ ), which may be either partiçulate or gaseous; $[A]_{\text {rain }}$ is the concentration of this species in rain, $\varepsilon$ is the in-cloud scavenging efficiency, and LWC is the liquid water content of rain at any level. This relationship was originally proposed 
for the scavenging of aerosols [Junge, 1963] and was later adapted to atmospheric gases [Brimblecombe and Dawson, 1984; Andreae et al., 1988]. Recent measurements clearly showed a dilution effect for $\mathrm{LWC}$ in convective rain events [Lacaux et al., 1992a], that is, departures from linearity due to dilution, so that it is suspected that $\varepsilon$ is not a constant. The dilution effect is more important for aerosol scavenging than for gas scavenging.

These experimental data originate from the DECAFE experiment but could presumably be more general in equatorial convective rains. In order to retrieve these features and to identify the main processes influencing the relationship between the concentration of a chemical species in precipitation, $[A]$, and the ground liquid water content LWCg, we have used a two-dimensional convection cloud model coupled to a chemical sulfur model to examine the scavenging of $\mathrm{SO}_{2}$ (gas) and $\mathrm{SO}_{4}^{2-}$ (aerosol).

After a short description of the model in section 2 and of the input data in section 3, we compare the model results with experimental data from the DECAFE experiment and from the ABLE 2B experiment [Garstang et al., 1990]. In section 4, we investigate the physical ( $\mathrm{LWCg}-R$ ) and the chemical (wet deposition and concentration) results using DECAFE and ABLE 2B data. Finally, in section 5, we focus on the relationship between $\overline{\mathrm{LWC}} \mathrm{g}$ and chemical content.

\section{The Model}

Following Ruthledge et al. [1986] and Taylor [1989], we have used a chemistry model coupled with a convective cloud model. This method allows us to represent the roles of the main physical processes in the simulation of the complex scavenging mechanisms in and below the clouds, commonly denoted by the term "wet deposition."

\subsection{Cloud Convection Model}

The model is a two-dimensional $(x, z)$, time-dependent, Eulerian cloud model. The spatial grid resolution is $200 \mathrm{~m}$. The dimension of the modeled region is $6.6 \mathrm{~km}$ in both the vertical and the horizontal. The basic framework of this study is described in detail by Liu and Orville [1969] and Orville and Kopp [1977]. Parameterizations are used to account for water phase changes (vapor, liquid, and ice). Five bulk water categories are considered here: vapor, cloud water, rain water, ice, and graupel. These hydrometeors interact through a variety of physical processes (e.g., condensation, evaporation, autoconversion, coalescence, accretion, collection, freezing, riming, and melting). The basic assumptions in the microphysical processes used are (1) a monodisperse, time invariant cloud droplet population in which the total number of droplets is fixed; (2) droplet coalescence (autoconversion) computed using the Kessler [1969] formulation with a threshold; and (3) rain and graupel distributions following Marshall and Palmer's [1948] distribution.

\subsection{Chemistry Model}

The present model deals primarily with sulfur chemistry because this compound is present under both phases, gas and aerosol, which will illustrate the contrasting behavior of gas $\left(\mathrm{SO}_{2}\right)$ and aerosol $\left(\mathrm{SO}_{4}^{2-}\right)$ in scavenging. Five chemical species are explicitly carried: $\mathrm{SO}_{2}, \mathrm{SO}_{4}^{2-}, \mathrm{NH}_{4}^{+}, \mathrm{O}_{3}$ and $\mathrm{H}_{2} \mathrm{O}_{2}$. The chemical species may exist in several forms: as gases $\left(\mathrm{SO}_{2}, \mathrm{O}_{3}\right.$ and $\left.\mathrm{H}_{2} \mathrm{O}_{2}\right)$, aerosols $\left(\mathrm{NH}_{4}\right)_{2} \mathrm{SO}_{4}^{2-}$, or as dissolved species $\left(\mathrm{SO}_{2}, \mathrm{SO}_{4}^{2-}, \mathrm{NH}_{4}^{+}, \mathrm{O}_{3}\right.$ and $\mathrm{H}_{2} \mathrm{O}_{2}$ ) within cloud water, rain water, ice, or graupel. The equations which describe the transformations between these forms are given by Taylor [1989]. All chemistry fields are advected. The principal assumptions are the following:

1. Over the relatively short timescales $(<1 \mathrm{~h})$ that characterize a convective cloud life, sulfur chemistry is dominated by aqueous phase processes, and therefore gas-phase chemistry can be neglected. This assumption is widely accepted [Calvert et al., 1985; Ruthledge et al., 1986].

2. With this condition, aqueous phase photochemical reactions are assumed to have a small effect on sulfate production.

Precipitation scavenging of $\left(\mathrm{NH}_{4}\right)_{2} \mathrm{SO}_{4}^{2-}$ exhibits several pathways: scavenging by nucleation or Brownian diffusion in cloud water and scavenging by impaction in rain water. For precipitation scavenging of gases, the transfer in water follows effective Henry's law, followed by an oxidation reaction in cloud water or rain water. The following equations are the main equations of the chemistry model:

$\mathrm{SO}_{2(\mathrm{~g})} \stackrel{K_{H}}{\longleftrightarrow} \mathrm{SO}_{2 .} \mathrm{H}_{2} \mathrm{O} \stackrel{K_{A 1}}{\longleftrightarrow} \mathrm{HSO}_{3^{-}}+\mathrm{H}^{+} \stackrel{K_{A 2}}{\longleftrightarrow} \mathrm{SO}_{3}^{2-}+2 \mathrm{H}^{+}$, where $K_{H}$ is $1.23 \mathrm{M} \mathrm{atm}^{-1}, K_{A 1}$ is $1.2310^{-2} \mathrm{M}$, and $K_{A 2}$ is $6.6110^{-8} \mathrm{M}$ [Seinfeld, 1986];

$$
\begin{aligned}
-\frac{d[S(I V)]}{d t}=\frac{d[S(V I)]}{d t}=\{ & \left\{k_{0}\left[\mathrm{SO}_{2} \mathrm{H}_{2} \mathrm{O}\right]\right. \\
& \left.+k_{1}\left[\mathrm{HSO}_{3}-\right]+k_{2}\left[\mathrm{SO}_{3}^{2-}\right]\right\}\left[\mathrm{O}_{3}\right],
\end{aligned}
$$

where $k_{0}$ is $2.410^{4} \mathrm{M}^{-1} \mathrm{~s}^{-1}, k_{1}$ is $3.710^{5} \mathrm{M}^{-1} \mathrm{~s}^{-1}$, and $k_{2}$ is $1.510^{9} \mathrm{M}^{-1} \mathrm{~s}^{-1}$ [Seinfeld, 1986];

$$
-\frac{d[S(I V)]}{d t}=\frac{d[S(V I)]}{d t}=\frac{\left\{k\left[H^{+}\right]\left[\mathrm{H}_{2} \mathrm{O}_{2}\right]\left[\mathrm{HSO}_{3}-\right]\right\}}{1+K\left[\mathrm{H}^{+}\right]}
$$

where $k$ is $7.4510^{7} \mathrm{M}^{-1} \mathrm{~s}^{-1}$ and $K$ is $13 \mathrm{M}^{-1}$ [Seinfeld, 1986].

With such a model, we can simulate only isolated clouds, not larger-scale phenomena. However, this limitation is unimportant here because, in the region under study, no spatially average rainfall or chemistry data are routinely available: a cloud convection model is a suitable tool to investigate data from a single station. Spatial integration of equatorial atmospheric chemistry is beyond the scope of the present paper. Moreover, although sulfurous compounds could seem not to be representative of the African chemistry (less, for example, than nitrogeneous or carbonaceous species), they are present under both phases, gas and aerosols, so that the modeling of the dilution effect is interesting.

\section{Model Initialization}

\subsection{Atmospheric Soundings}

Owing to a lack of experimental local atmospheric soundings from DECAFE, we have used as model input a sounding which characterizes the wet season in equatorial Amazonia, taken from ABLE 2B data [Schmit et al., 1990]. The chosen profile was recorded on May 5, 1987, at $1200 \mathrm{LT}$ in Belem $\left(1.4^{\circ} \mathrm{S}, 48.5^{\circ} \mathrm{W}\right)$. It has been slightly modified so as to produce five different temperature and dew temperature 

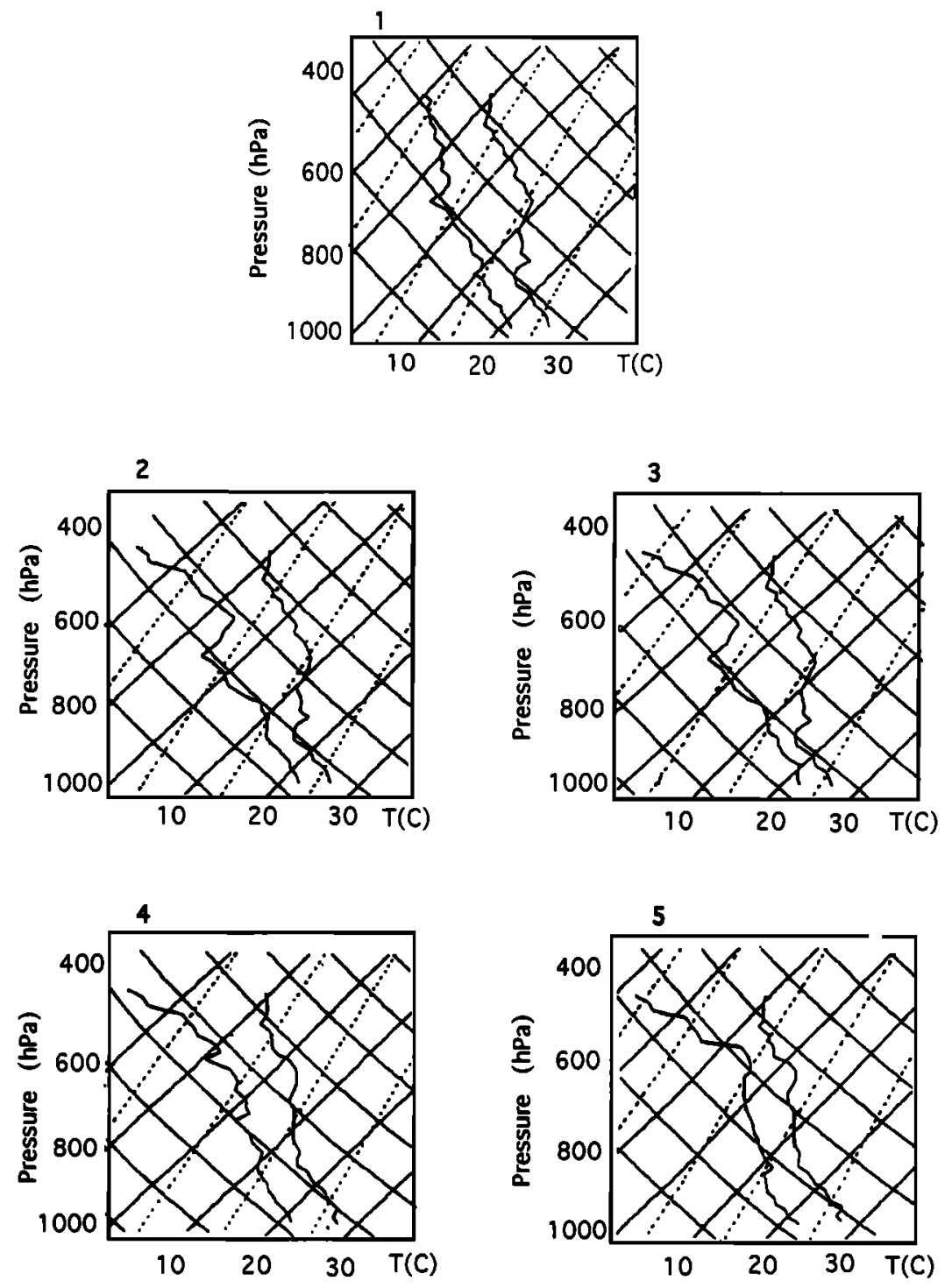

Figure 1. Initial soundings (emagram) for the five runs.

profiles leading to five different cloud development and precipitation regimes which cover the DECAFE experimental mean weighted ground liquid water content $\mathrm{LWCg}$ range (see section 4). The initial profiles are shown in Figure 1.

\subsection{Chemical Atmospheric Profiles}

Since atmospheric chemical profiles of $\mathrm{SO}_{2}$ and $\mathrm{SO}_{4}^{2-}$ aerosol were not available at Enyéle, the vertical distributions of these species were taken from ABLE 2B measurements [Andreae et al., 1990a]. We have used for all runs an initial $\mathrm{H}_{2} \mathrm{O}_{2}$ of $1.5 \mathrm{ppb}$ over the entire domain, corresponding to the initial conditions proposed by Lelieveld and Crutzen [1990] for equatorial latitudes. Two scenarios are considered:

3.2.1. ABLE $2 B$ mean profiles or profile 1. The initial $\mathrm{SO}_{2}$ and $\mathrm{SO}_{4}^{2-}$ profiles, denoted as curve a in Figure 2, are characteristic of equatorial forest sulfur emissions by soil and vegetation which appear to be similar in both Amazonian and African equatorial forests [Bingemer et al., 1992]. The profile of $\mathrm{O}_{3}$ (curve a in Figure 3 ) corresponds to the average wet season profile in Amazonia [Kirchhoff et al.,
1990]. The results of this first simultions series will be compared in subsection 4.2.1. to the mean rain sulfate concentration (1.6 $\mu \mathrm{eq} 1^{-1}$ ) in Amazonian forests in the wet season [Andreae et al., 1990b].

3.2.2. ABLE $2 B$ profiles with biomass burning or profile 2. The mean sulfate concentration of convective rains in North and South Congo $\left(8.5 \mu \mathrm{eq} 1^{-1}\right.$ and $6.2 \mu \mathrm{eq} 1^{-1}$, respectively) during the rainy season is more than 4 times the value obtained during ABLE 2B (1.6 $\left.\mu \mathrm{eq} 1^{-1}\right)$. Congo precipitation also shows increased concentrations and wet depositions of $\mathrm{NO}_{3}^{-}, \mathrm{C}_{2} \mathrm{O}_{4}^{2-}$ and $\mathrm{NH}_{4}^{+}$as compared to Amazonia precipitation especially during the dry season [Lacaux et al., 1991, 1992a, b; Lefeivre, 1993]. These authors showed that such high chemical concentrations in rain can originate from the emission of gaseous $\left(\mathrm{SO}_{2}, \mathrm{NO}_{\mathbf{y}}, \mathrm{NH}_{3}\right)$ and particulate $\left(\mathrm{SO}_{4}^{2-}, \mathrm{NO}_{3}^{-}, \mathrm{C}_{2} \mathrm{O}_{4}^{2-}\right.$, and $\mathrm{NH}_{4}^{+}$) compounds by savanna fires of both southern and northern hemispheres which are systematically advected over the African equatorial forest by Intertropical Convergence Zone mechanisms. This observation is supported also by several 

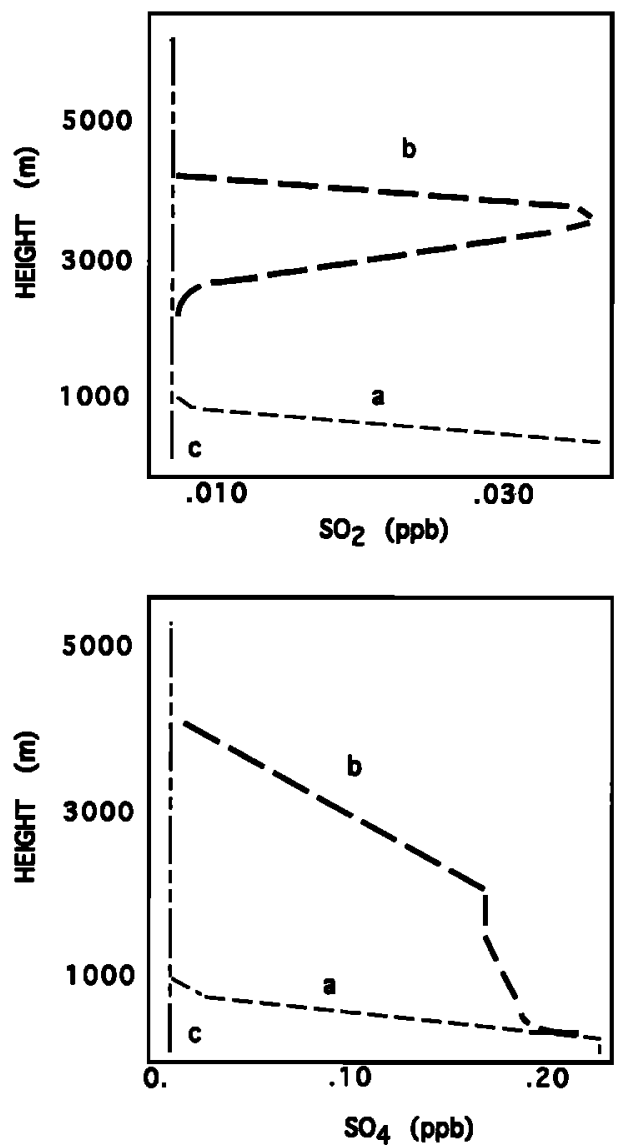

Figure 2. (top) Initial $\mathrm{SO}_{2}$ and (bottom) $\left(\mathrm{NH}_{4}\right)_{2} \mathrm{SO}_{4}$ profiles [Andreae et al., 1990]. Curve a shows ABLE 2B mean profiles (or profile 1); curve b shows dust episode (ABLE 2B) on April 29, 1989 (or profile 2); curve c shows background profiles $\left(\mathrm{SO}_{2}=7 \mathrm{ppt} ;\left(\mathrm{NH}_{4}\right)_{2} \mathrm{SO}_{4}=11 \mathrm{ppt}\right)$.

experimental studies during DECAFE in 1988 which proved that a synoptic transport of burning residues during the dry season actually increases the concentration of $\mathrm{O}_{3}, \mathrm{CO}$ [Andreae et al., 1992], hydrocarbons [Rudolph et al., 1992] and organic acids [Helds et al., 1992] between 1 and $3 \mathrm{~km}$ in altitude in the tropospheric layer.

In order to illustrate the model response to such an enrichment due to advection processes, we have modified the initial ABLE 2B profiles of $\mathrm{SO}_{2}$ and $\mathrm{SO}_{4}^{2-}$ (curve b in Figure 2) using the vertical distribution of sulfur dioxide and sulfate from the dust episode of April 29, 1989 [Andreae et al., 1990a]. These modified profiles are referred to as profile 2. The influence of $\mathrm{O}_{3}$ enrichment on the aqueous oxidation is also studied using the $\mathrm{O}_{3}$ profile issued from DECAFE 88 experiment (curve $b$ in Figure 3) during the dry season [Cros et al., 1991]. The results of these simulations are discussed in Section 4.2.2.

\section{Results and Discussion}

For each of the primary variables calculated by the model (liquid water content at ground level LWCg, rainfall height $H$, precipitation rate $R$, wet deposition, and species concentration), two types of results are presented:

1. Global results represent an average over all the grid points on the ground for rainfall that had a threshold of 0.1 $\mathrm{mm} \mathrm{h}^{-1}$.

2. When comparing model results with local measurements, we used results at the center of the ground domain. These data are referred to as "central point" results.

Finally, in order to study the relationship between chemical concentration and liquid water content, we used the ground mean weighted liquid water content $\overline{\mathrm{LWC}}$. This value is averaged for each rain event and is calculated as follows:

$$
\overline{\mathrm{LWC}} \mathrm{g}=\Sigma \mathrm{H} \boldsymbol{i} \mathbf{L W C g} / \mathbf{\Sigma}(\mathrm{Hi})
$$

where $\mathrm{Hi}$ (in millimeters) is the height of rain recorded or modeled at ground level every minute. The use of $\mathrm{Hi}$ as a weighting coefficient tends to give more representative values than the arithmetic means because it takes into account the respective contributions of the stratiform and the convective parts to the total amount of water, therefore higlighting the experimental rain events.

\subsection{Physical Parameters LWCg, R}

The measurements of liquid water content were obtained using a RD69 disdrometer [Campistron et al., 1987], which measures the drop size spectrum of the rain at 1-min intervals. The rain intensity data were recorded with an automatic precipitation collector [Lacaux and Warburton, 1980].

In Figures $4 a$ and $4 b$, the evolution of $L W C g$ (in grams per cubic meter) and $R$ (in millimeters per hour) for the central point are shown for the five soundings. Comparison with a typical experimental convective rain on June 24, 1988 (Figures $4 \mathrm{c}$ and $4 \mathrm{~d}$ ), suggests that the model curves are realistic for $\mathrm{LWCg}$ and $R$ except at the end of the simulation (after 20 min simulation time), where an asymmetry is observed in experimental data.

Table 1 presents a summary of the main model results, along with a comparison with experimental data. A satisfactory agreement is found between the time-averaged model $\overline{\mathrm{LWC}} \mathrm{g}$ at the central point (between $0.57 \mathrm{~g} \mathrm{~m}^{-3}$ and $4.56 \mathrm{~g} \mathrm{~m}^{-3}$ ) and its experimental values (between $0.43 \mathrm{~g} \mathrm{~m}^{-3}$ and $3.89 \mathrm{~g} \mathrm{~m}^{-3}$ ).

For both model and experimental data, a least squares fit was applied to the raindrop distribution in order to obtain a

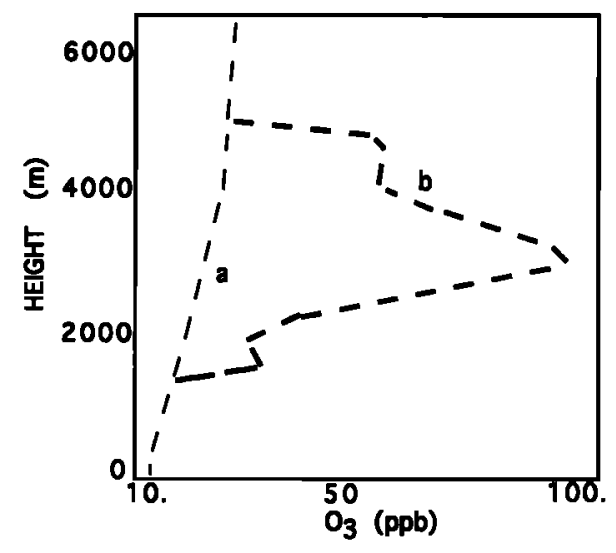

Figure 3. Initial $\mathrm{O}_{3}$ profile. Curve a shows the mean wet season profile in Amazonia [Kirchhoff et al., 1990], while curve b shows ozone profile measured near Brazzaville on June 20, 1986, in dry season [Cros et al., 1991]. 

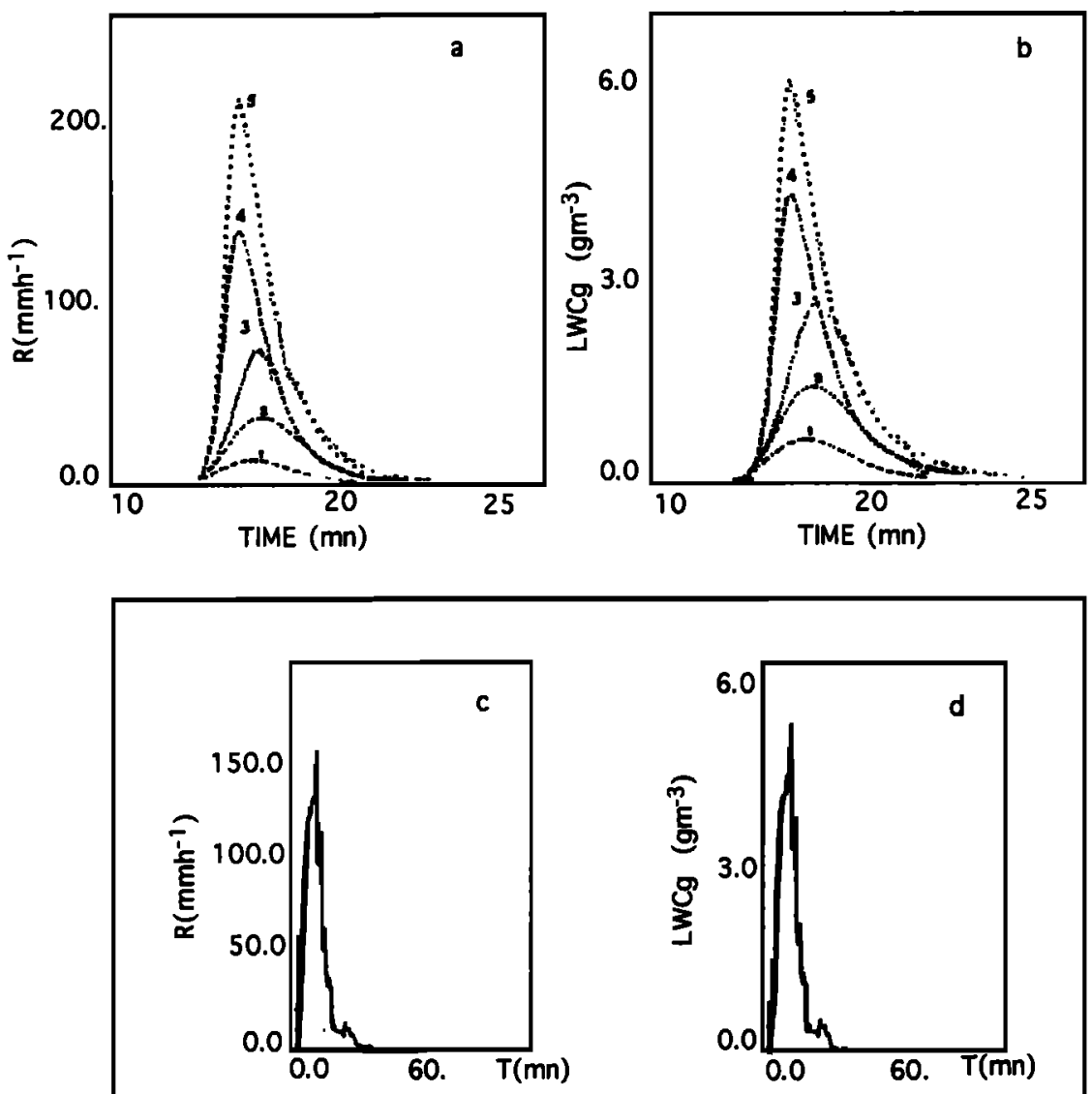

Figure 4. Evolution of (a) average intensity $R$ and (b) average liquid water content $L W C_{g}$ for five runs at the central point. Evolution of experimental intensity $R$ (c) and $\mathrm{LWCg}$ (d) of the convective rain collected on June 24, 1988, at Enyélé (North Congo), where $R_{\max }=154.3 \mathrm{~mm} \mathrm{~h}^{-1}$ and $\mathrm{LWC}_{\max }=5.8$ $\mathrm{gm}^{-3}$.

relationship between $L W C g$ and $R$ corresponding to a power law of the form:

$$
\mathrm{LWCg}=a R^{b}
$$

LWCg (in grams per cubic meter) and $R$ (in millimeters per hour) are the ground liquid water content and the precipitation rate calculated from recorded or modeled values every minute, respectively. The experimental and modeled values of $\mathrm{LWCg}$ and $R$ are displayed in Table 2 and Figure 5. For the 47 convective events collected at Enyele, the values of coefficient $a$ and of the exponent $b$ are $a=$ 0.057 and $b=0.90$. The correlation coefficient is $r=0.997$.

Table 1. Summary of the Main Model Results

\begin{tabular}{|c|c|c|c|c|c|c|}
\hline \multirow{2}{*}{$\begin{array}{l} \\
\text { Average } \\
\text { Rainfall }\end{array}$} & \multicolumn{5}{|c|}{ Runs } & \multirow{2}{*}{$\begin{array}{c}\text { Experimental } \\
\text { Amount } \\
\text { (North Congo), } \\
N=47\end{array}$} \\
\hline & 1 & 2 & 3 & 4 & 5 & \\
\hline $\begin{array}{l}D t, \mathrm{mn} \\
R, \mathrm{~mm} \mathrm{~h}^{-1} \\
\mathrm{LWCg}, \mathrm{g} \mathrm{m}^{-3}\end{array}$ & $\begin{array}{r}11.3 \\
8.7 \\
0.5\end{array}$ & $\begin{array}{r}14.5 \\
24.1 \\
1.1\end{array}$ & $\begin{array}{l}\text { Global } \\
17.3 \\
30.3 \\
1.9\end{array}$ & $\begin{array}{r}13.8 \\
85.4 \\
3.0\end{array}$ & $\begin{array}{r}15.5 \\
126.0 \\
4.1\end{array}$ & \\
\hline $\begin{array}{l}D t, \mathrm{mn} \\
H, \mathrm{~mm}^{-1} \\
\bar{R}, \mathrm{~mm} \mathrm{~h}^{-1} \\
\mathrm{LWCg}, \mathrm{g} \mathrm{m}^{-3}\end{array}$ & $\begin{array}{r}11.3 \\
1.1 \\
11.2 \\
0.6\end{array}$ & $\begin{array}{r}14.5 \\
3.4 \\
32.2 \\
1.3\end{array}$ & $\begin{array}{l}\text { Central } \\
17.3 \\
7.2 \\
67.4 \\
2.4\end{array}$ & $\begin{array}{r}13.8 \\
8.1 \\
112.0 \\
3.5\end{array}$ & $\begin{array}{r}15.5 \\
14.6 \\
169.0 \\
4.8\end{array}$ & $\begin{array}{l}9-46.8 \\
1.9-35.7 \\
9.4-102 . \\
0.4-3.8\end{array}$ \\
\hline
\end{tabular}


Table 2. Values of $a, b$ and $r^{2}$ for Different Runs and for Experimental Values From North Congo

\begin{tabular}{|c|c|c|c|c|c|c|}
\hline \multirow{2}{*}{$\begin{array}{l}\text { Relationships } \\
\mathrm{LWCg}=a R^{b}\end{array}$} & \multicolumn{5}{|c|}{ Runs } & \multirow{2}{*}{$\begin{array}{c}\text { Experimental } \\
\text { Amount } \\
\text { (North Congo) } \\
N=47\end{array}$} \\
\hline & 1 & 2 & 3 & 4 & 5 & \\
\hline $\begin{array}{l}a \\
b \\
r^{2}\end{array}$ & $\begin{array}{l}0.075 \\
0.85 \\
0.996\end{array}$ & $\begin{array}{l}0.077 \\
0.83 \\
0.995\end{array}$ & $\begin{array}{l}0.081 \\
0.81 \\
0.996\end{array}$ & $\begin{array}{l}0.081 \\
0.81 \\
0.994\end{array}$ & $\begin{array}{l}0.082 \\
0.80 \\
0.994\end{array}$ & $\begin{array}{l}0.057 \\
0.897 \\
0.994\end{array}$ \\
\hline
\end{tabular}

Values of 5992-min recordings for $N=47$ convective rain events ( $r$ is the correlation coefficient) are given.

Whereas the model exponent values $(b)$ are slightly lower than experimental values, the model coefficients $(a)$ are systematically higher than experimental, thereby compensating the lower values of $b$. As may be seen in Figure 5, the model results agree with the experimentally determined curve of $R$-LWCg. The ground convective cloud model results compare satisfactorily to precipitation measurements at Enyélé.

\subsection{Wet Deposition}

4.2.1. Model Runs with profile 1. The evolution of wet deposition from aerosol or gas scavenging is shown in Figure 6 for all runs. In these figures, we observe that their pattern follows the evolution of liquid water content and intensity (Figures $4 \mathrm{a}$ and $4 \mathrm{~b}$ ).

In Table 3, we show the principal time-averaged results, which are as follows:

1. The sulfate concentration from aerosol $\left[\mathrm{SO}_{4} A\right]$ is a decreasing function of precipitation rate (run 1: weak precipitation; run 5: heavy precipitation). However, the same behavior is not found for sulfate originating from $\mathrm{SO}_{2}$ (gas), that is, $\left[\mathrm{SO}_{4} G\right]$, which is almost constant: the dilution effect is more important for concentration of species from aerosol scavenging than for concentration of species from gas scavenging.

2. The model time-averaged central concentrations in total sulfate, that is, originating form both gas and aerosol $\left[\mathrm{SO}_{4} \mathrm{~T}\right]$ varies between $0.58 \mu \mathrm{eq} \mathrm{I}^{-1}$ and $3.20 \mu \mathrm{eq} \mathrm{l}^{-1}$, while ABLE 2B experimental value was $1.6 \mu \mathrm{eq} 1^{-1}$ for convective precipitation [Andreae, 1990b.]

3. The model time-averaged central sulfate wet deposi-

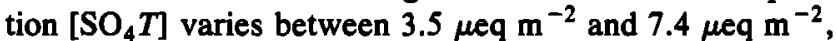
while the ABLE 2B experimental value was $8.2 \mu \mathrm{eq} \mathrm{m}^{-2}$ [Andreae, 1990B].

4.2.2. Model runs with profile 2. Figure 7 shows the evolution of wet deposition from aerosol and gas. For every run, the concentrations and depositions (Table 4) are larger than for profile 1, shown in Table 4. The (decreasing) relationship between concentrations and precipitation rate is much less obvious. This may be explained as follows: in the previous case, sulfate concentrations in the cloud area are low, and removel is achieved mainly below the cloud by washout: a heavy rain is associated with a low ground content and reverse. With profile 2 , the in-cloud sulfate concentrations are much greater, and rainout probably predominates. The scavenging is never complete; however strong the rain rate may be (within the limits of our numerical experiment), sulfate is always available. This may be seen in Figure 8; with profile 1, the atmospheric sulfate concentrations are severly depleted, whereas they remain high with profile 2. Moreover, rainout removal efficiency is weaker than washout [Lin Xing and Chameides, 1990].

The central total concentration in sulfate, $\left[\mathrm{SO}_{4} T\right]$, ranges between 2.5 and $5.6 \mu \mathrm{eq} \mathrm{I}^{-1}$ (Table 4). These values are lower than the concentrations measured during the wet season in both South Congo [Lacaux et al., 1992a] and North Congo [Lefeivre, 1993]: $6.2 \mu \mathrm{eq} 1^{-1}$ and $8.5 \mu \mathrm{eq} 1^{-1}$, respectively. Two main reasons can partly explain this underprediction by the model:

1. We did not consider an enrichment of tropospheric ozone concentration which is commonly associated with biomass burning emissions [Cros et al., 1988, 1991; Marenco et al., 1990; Andreas et al., 1992].

2. The initialization enriched profiles of $\mathrm{SO}_{2}$ and $\mathrm{SO}_{4}^{2-}$ issued from measurements in Amazonia are only partly representative of actual advection of combustion products over the African equatorial forest because the savanna fires in Africa are of a much greater extent than in Amazonia.

In order to estimate the impact of a simulaneous tropospheric enrichment of $\mathrm{O}_{3}$, we carried out a special run for sounding 4 with the experimental $\mathrm{O}_{3}$ profile (curve b in Figure 3) issued from DECAFE 88 in Congo during the dry season [Cros et al., 1991]. This simulation (Table 4 and Figure 9) illustrates the role of tropospheric ozone in gassulfate transformation (oxidation processes). Two runs have been performed using the same sulfate profiles (curve $b$ in Figure 2) but with two different $\mathrm{O}_{3}$ profiles (Figure 3); in curve b of Figure 3, the $\mathrm{O}_{3}$ concentration has been multiplied by a factor of about 2 between 1500 and $5000 \mathrm{~m}$. The increase in rain sulfate content from $\mathrm{SO}_{2}$ (gas) amounts to $60 \%$. This is much greater than the increase originating from the enrichment in $\mathrm{SO}_{2}$ itself, which is about $14 \%$, with curve a of $\mathrm{O}_{3}$ (Figure 3). However, the concentration in total sulfate is increased only slightly.

Moreover, the modeled sulfate rain content increases from 1.91 to $2.43 \mu \mathrm{eq} 1^{-1}$ when profile 1 is replaced by profile 2 . This enrichment is of the same order of magnitude as the experimental enrichment observed in convective rains in North Congo between the dry and wet seasons (1.4 to 2.7 $\left.\mu \mathrm{eq} \mathrm{I}^{-1}\right)$ for the five characteristic compounds $\left(\mathrm{SO}_{4}^{2-}, \mathrm{NO}_{3}^{-}\right.$, $\mathrm{C}_{2} \mathrm{O}_{4}^{2-}$, and $\mathrm{NH}_{4}^{+}$).

Since the model results seem realistic and rather consistent with experimental ABLE 2B and DECAFE data, we compare in the following section the relationships between LWCg and sulfate from aerosol or gas with experimental 

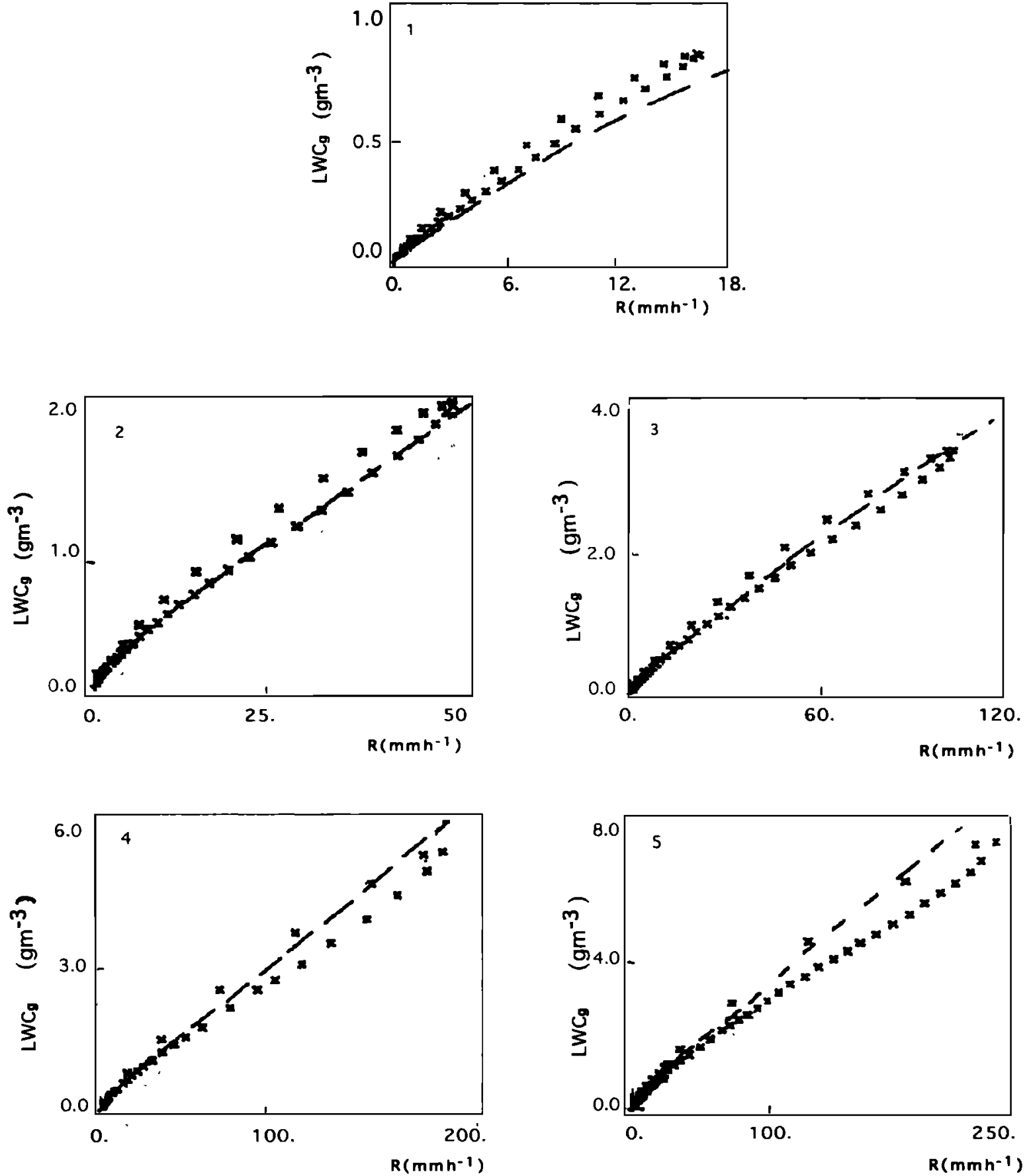

Figure 5. Correlation between $\mathrm{LWCg}$ and $R$ for five runs (crosses) and for experimental data (dashed line) with 1-min interval integration.

regressions relating $[A]$ and $\overline{L W C}$ in North Congo precipitations.

\section{Relation Between Liquid Water Content and Chemical Concentration}

If $\varepsilon$ in Junge's relationship (equation (2)) is assumed to be constant, then the relationship between $\overline{\mathrm{LWC}} \mathrm{g}$ and concentration is linear, and the slope is unity:

$$
\frac{[A]_{\text {rain } 0}}{[A]_{\text {rain }}}=\frac{\overline{L W C g}}{\overline{L W C} g_{0}}
$$

Let the index 0 refer to a fixed (reference) value. For $\overline{\mathrm{LWC}} \mathrm{g}$, we choose the weakest value, that is, $0.57 \mathrm{gm}^{-3}$. We plotted the ratio of experimental concentrations $C_{D}=$ $[A]_{\text {raino }} /[A]_{\text {rain }}$ versus experimental $\overline{L W C g}$ at Enyéle (Figure $10)$ as well as for the five model runs. The ratio $C_{D}$ is referred to as the dilution coefficient. We notice different 


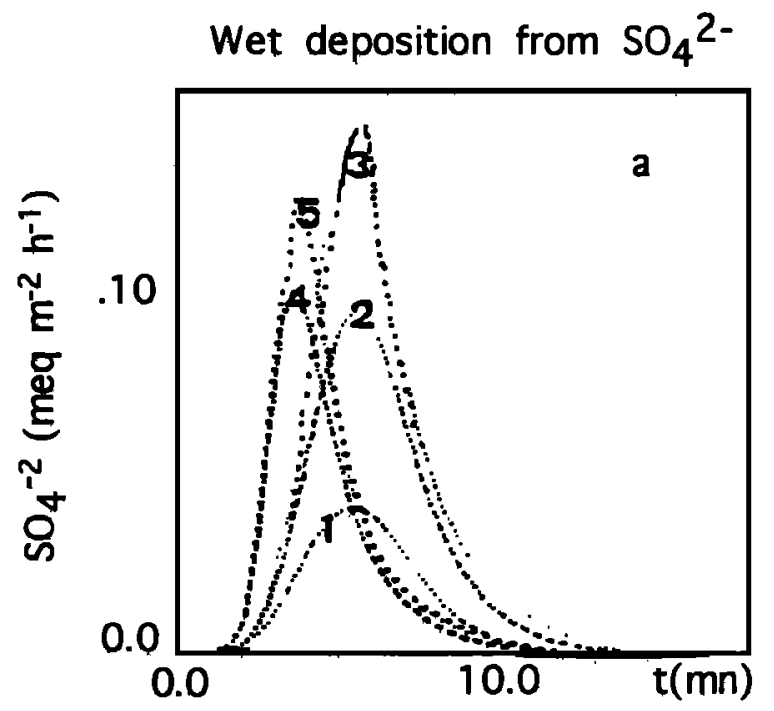

Wet deposition from $\mathrm{SO}_{2}$

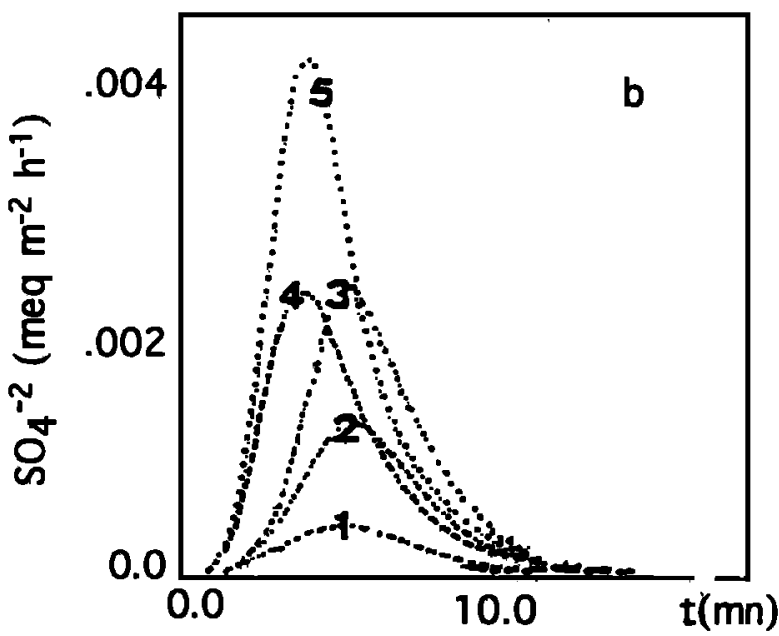

Figure 6. Evolution of wet deposition of sulfate $\left(m e q m^{-2} h^{-1}\right.$ ) from (a) aerosol and (b) gas for five runs using chemical profile 1 .

patterns according to the origin (either aerosol or gas) of the trace elments, but the prominent feature is that none of the curves is linear. The agreement is satisfactory for aerosol, as the model curyes replicate the experimental dilution coefficient. The slopes of the curves for gas are much lower, and the agreement with model results is less satisfactory. Nevertheless, the modeled $C_{D}$ values for gas are lower than the modeled $C_{D}$ values for aerosols, which agrees with the experiment. The model curves depend on initial profiles and show an important influence of the vertical distribution and therefore of the origin of the scavenged compounds. To compare the scavenging of $\mathrm{SO}_{2}$ and $\left(\mathrm{NH}_{4}^{+}\right)_{2} \mathrm{SO}_{4}^{2-}$ as a function of $\overline{\mathrm{LWC}} \mathrm{g}$, we carried out another run applied to background concentrations in $\mathrm{SO}_{2}$ and $\left(\mathrm{NH}_{4}^{+}\right)_{2} \mathrm{SO}_{4}^{2-}$ (7 and $11 \mathrm{ppt}$, respectively) uniformly distributed over the whole vertical profile (curve $\mathrm{c}$ in Figure 2). In this case, the dilution coefficient is weaker than for profiles 1 or 2 . The concentrations $\left[\mathrm{SO}_{4} \mathrm{G}\right]$ and $\left[\mathrm{SO}_{4} \mathrm{~A}\right]$ in the rain confirm the different behavior of sulfate from gas or aerosol in comparison with the dilution effect (Table 4 and Figure 10). These simulated and experimental results show the following:
1. The factor $\varepsilon$ cannot be a constant; otherwise, the curves would be straight lines with a slope unity; linearity is observed only for weak values of $\overline{L W C g}$, so that the Junge's relation could be valid for stratiform rains but not for strong convective rains.

2. In both cases, gas and aerosol, a greater $\overline{\mathrm{LWC}}$, that is, a greater rain rate $R$, following equation (3), results in a weaker suflate content. Moreover, differences between scavenging processes are obvious, depending on the phase (either gas or aerosol) of the pollutant; the decay of the amount of scavenged matter is slower for gases than for aerosols. In experimental curves, when $\overline{\mathrm{LWC}} \mathrm{g}$ is multiplied by about 10 , the concentration for gas is only halved; on the other hand, it is reduced by a factor of 3.5 for aerosols. The dilution effect is therefore more important for aerosols than for gases. The scavenging processes are different.

\section{Conclusion}

We have presented a convection model coupled with a chemistry model describing sulfate scavenging processes in

Table 3. Ground Concentrations and Wet Deposition for Five Runs and Experimental Values From ABLE 2B

\begin{tabular}{|c|c|c|c|c|c|c|}
\hline \multirow[b]{2}{*}{ Profile 1} & \multicolumn{5}{|c|}{ Runs } & \multirow{2}{*}{$\begin{array}{c}\text { Experimental } \\
\text { Amount, } \\
\text { ABLE 2B }\end{array}$} \\
\hline & 1 & 2 & 3 & 4 & 5 & \\
\hline \multicolumn{7}{|c|}{ Concentration, reg $l^{-1}$} \\
\hline$\left[\mathrm{SO}_{4} A\right]$ & 3.17 & 2.36 & 1.63 & 0.72 & 0.55 & \\
\hline$\left[\mathrm{SO}_{4} G\right]$ & 0.028 & 0.028 & 0.027 & 0.021 & 0.022 & \\
\hline$\left[\begin{array}{ll}\mathrm{SO}_{4} & \mathrm{~T}\end{array}\right]$ & 3.20 & 2.39 & 1.66 & 0.74 & 0.58 & 1.6 \\
\hline \multicolumn{7}{|c|}{ 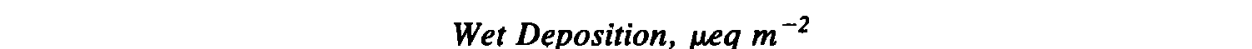 } \\
\hline$\left[\mathrm{SO}_{4} \mathrm{~A}\right]$ & 3.49 & 8.05 & 11.77 & 5.82 & 7.15 & \\
\hline$\left[\mathrm{SO}_{4} G\right]$ & 0.031 & 0.095 & 0.195 & 0.170 & 0.284 & \\
\hline$\left[\begin{array}{ll}\mathrm{SO}_{4} & T\end{array}\right]$ & 3.52 & 8.15 & 11.96 & 5.99 & 7.43 & 8.2 \\
\hline
\end{tabular}

Runs are initialized by chemical ABLE 2B profiles or profile 1 (curve a in Figures 2 and 3). $\mathrm{SO}_{4} \mathrm{~A}, \mathrm{SO}_{4} \mathrm{G}$, and $\mathrm{SO}_{4} \mathrm{~T}$ are the aerosol or gas originating sulfate and the total sulfate rain content, respectively. 

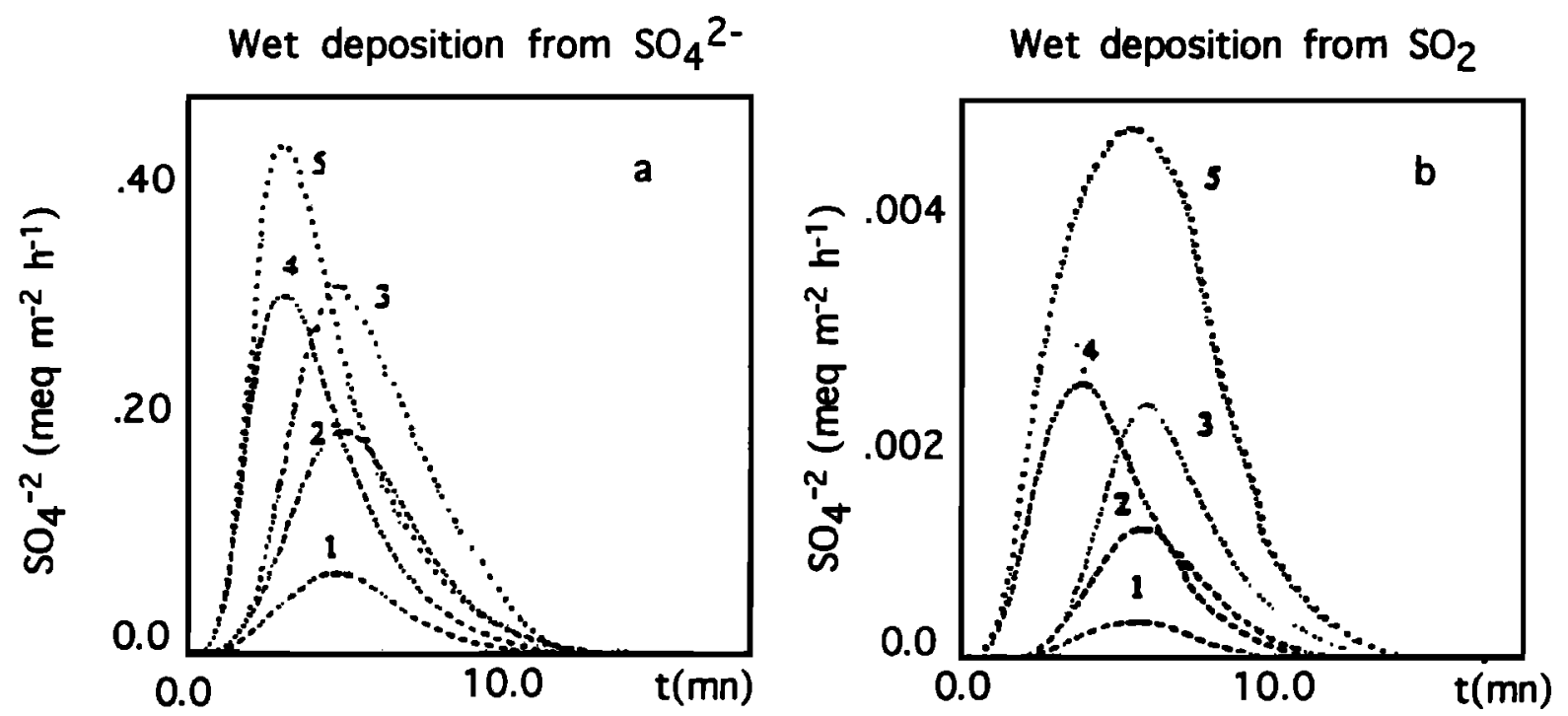

Figure 7. Evolution of wet deposition of sulfate (meq $\mathrm{m}^{-2} \mathrm{~h}^{-1}$ ) from (a) aerosol and (b) gas for five runs using chemical profile 2 .

the atmosphere. As a first step, this model has been calibrated with the help of precipitation data from the DECAFE experiment in equatorial Africa. This resulted in a relation between the liquid water content $\mathrm{LWCg}$ and the rain rate $R$ consistent with the experimental data. The second step consisted of a comparison beween model and experimental estimations of ground sulfate content and wet deposition. The experimental data set came from the DECAFE (Congolese forest) and ABLE 2B (Amazonian forest) experiments. The suflate concentrations in the modeled rains resulting from scavenging of experimental $\mathrm{SO}_{2}$ and $\mathrm{SO}_{4}^{2-}$ vertical distributions in the Amazonian forest during the wet season are consistent with experimental measurements. The simulation of the enrichment in $\mathrm{SO}_{2}$ and $\mathrm{SO}_{4}^{2-}$ originating from advection process provided an explanation of the experimental increase in chemical content of rains observed during the dry season in the African equatorial forest (Congo) for these compounds characteristic of bush fires $\left(\mathrm{SO}_{4}^{2-}, \mathrm{NO}_{3}^{-}\right.$, $\mathrm{C}_{2} \mathrm{O}_{4}^{2-}$, and $\mathrm{NH}_{4}^{+}$).

Finally, we have proposed an explanation for the link between the ground liquid water content $\overline{L W C g}$ and the ground suflate content in rain water. We have retrieved the observed resutls, at least qualitatively. The relation between $\overline{\mathrm{LWC}} \mathrm{g}$ and sulfate content is different according to the origin (gas or aerosol) of the scavenged sulfur. In both cases the relationship is nonlinear; the dilution effect with increasing $\overline{\mathbf{L W C}}_{\mathbf{g}}$ is more important for aerosols than for gases. We show experimentally and numerically that the relationship between $\overline{\mathrm{LWC}}$ and $C_{D}$ is not linear, and therefore the use of the Junge's relationship is somewhat risky for the cases of convective rains.

The comparison of simulated and experimental [A]$\overline{\mathrm{LWC}} \mathrm{g}$ relationships allowed us to identify the main processes responsible for the dilution effect, which are (1) in the

Table 4. Ground Concentrations for Five Runs and Experimental Values From DECAFE

\begin{tabular}{|c|c|c|c|c|c|c|}
\hline \multirow[b]{2}{*}{ Profile 2} & \multicolumn{5}{|c|}{ Runs } & \multirow{2}{*}{$\begin{array}{c}\text { Experimental } \\
\text { Amount, } \\
\text { DECAFE } \\
\text { North Congo }\end{array}$} \\
\hline & 1 & 2 & 3 & 4 & 5 & \\
\hline \multicolumn{7}{|c|}{ Concentration, $\mu e q l^{-1}$} \\
\hline$\left[\mathrm{SO}_{4} \mathrm{~A}\right]$ & 5.6 & 5.13 & 4.26 & 2.82 & 2.46 & \\
\hline$\left[\mathrm{SO}_{4} G\right)^{*}$ & 0.028 & 0.029 & 0.028 & 0.024 & 0.029 & \\
\hline$\left[\mathrm{SO}_{4} \mathrm{~T}\right]$ & 5.63 & 5.16 & 4.29 & 2.84 & 2.49 & 8.5 \\
\hline$\left[\mathrm{SO}_{4} \mathrm{~A}\right]$ & & & & 2.82 & & \\
\hline$\left[\mathrm{SO}_{4} \mathrm{G}\right] \dagger$ & & & & 0.038 & & \\
\hline$\left[\begin{array}{ll}\mathrm{SO}_{4} \mathrm{~T} & \mathrm{~T}\end{array}\right]$ & & & & 2.86 & & \\
\hline
\end{tabular}

*This run was initialized by chemical ABLE 2B profiles with biomass burning or profile 2 (curve $b$ of Figure 2 and curve a of Figure 3 ).

$†$ This run was initialized by profile 2 for $\mathrm{SO}_{2}, \mathrm{SO}_{4}^{2-}$ (curve $b$ in Figure 2) and DECAFE ozone profile (curve $b$ in Figure 3). 

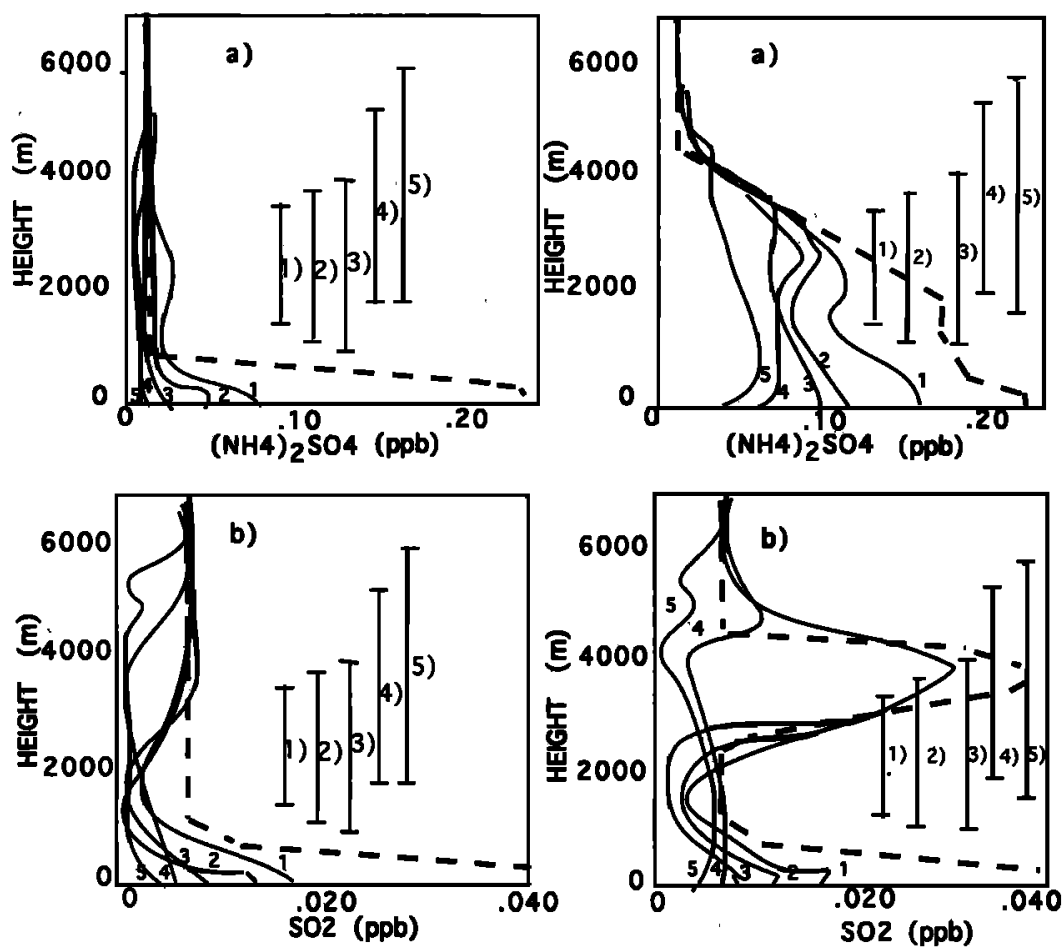

Figure 8. $\mathrm{SO}_{2}$ and $\mathrm{SO}_{4}^{2-}$ profiles for five runs (dashed line for initial; solid line for $R$ maximum): (a) using profile 1; (b) using profile 2. Vertical segments represent the cloud vertical extent.

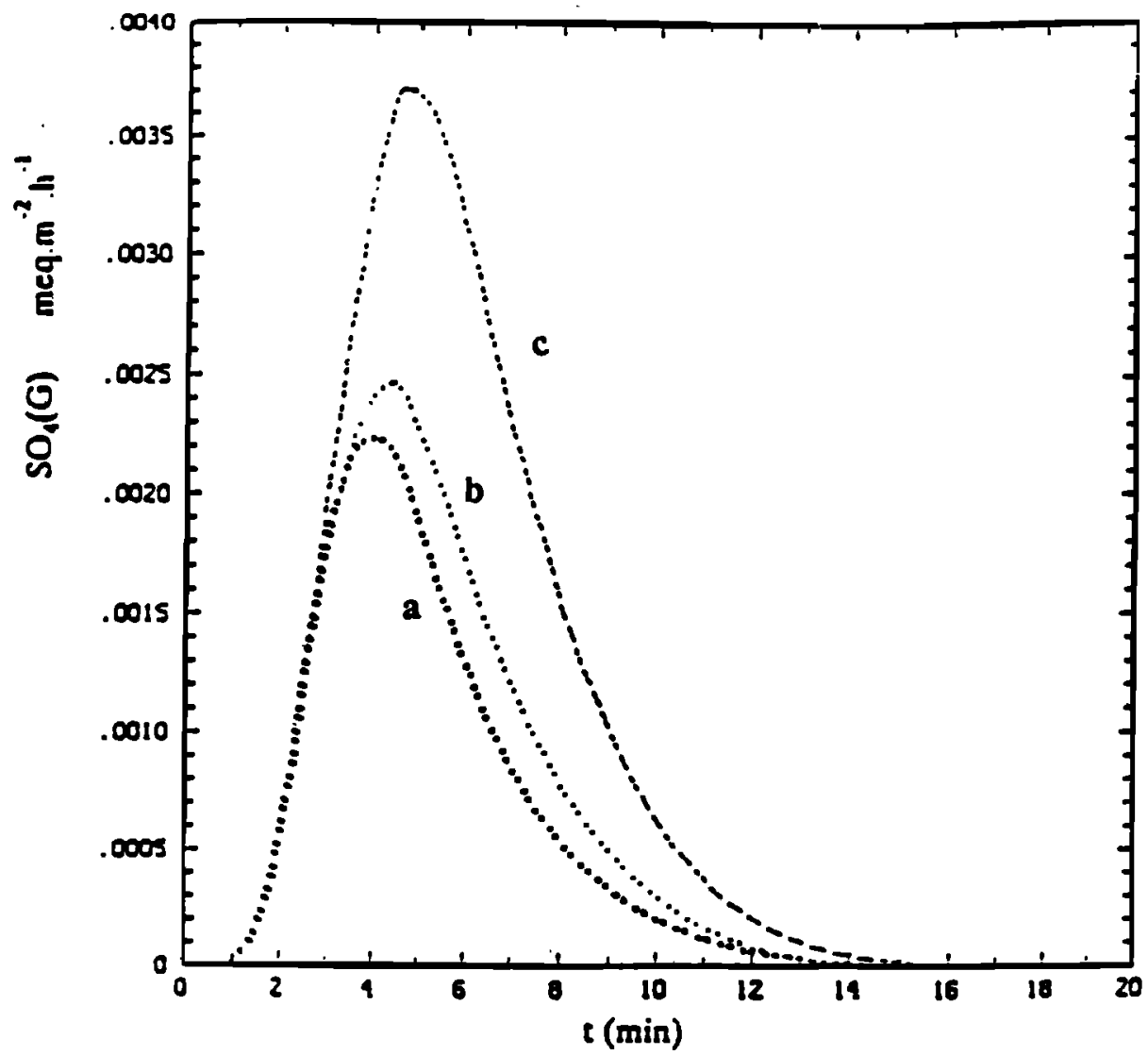

Figure 9. Evolution of wet deposition of sulfate $\left(\mathrm{meq} \mathrm{m}^{-2} \mathrm{~h}^{-1}\right)$ with curve a indicating chemical profile 1 (Figures $2 a$ and $3 a$ ), curve $b$ indicating chemical profile 2 (curve $b$ in Figure 2 and curve $a$ in Figure 3); (c) chemical profile 2 for $\mathrm{SO}_{2}$ and $\mathrm{SO}_{4}$ (curve $b$ in Figure 2) and DECAFE ozone profile (curve b in Figure 3). 


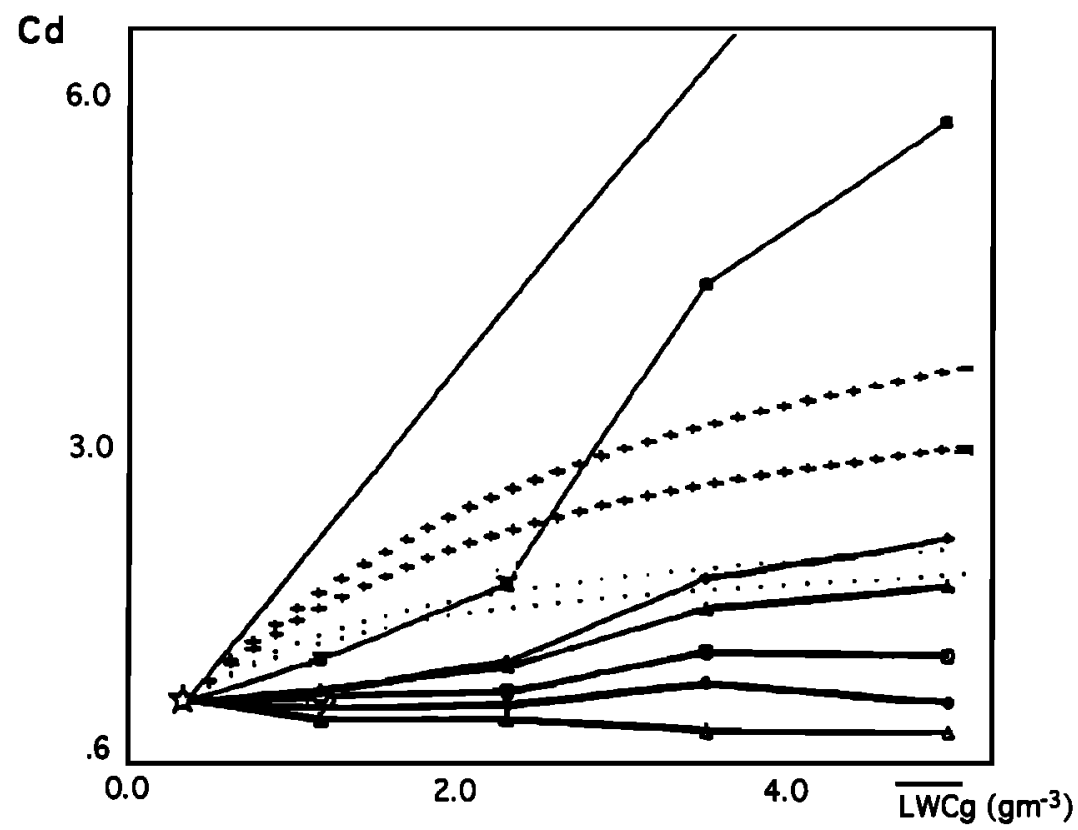

Figure 10. Model and experimental relationships between $\overline{\mathrm{LWC}} \mathrm{g}$ and dilution coefficient $C_{D}$ according to the origin and to the vertical distribution of the removed species. $\left(C_{D}=[A]_{\text {rain } 0} /[A]_{\text {rain }}\right)$. The solid diagonal line shows the case where $\varepsilon$ is constant $\left(C_{D}=\mathrm{LWCg} / \mathrm{LWCg}\right.$ ). Solid triangles denote origin from aerosol, while open triangles denote origin from gas, run using background profiles of $\mathrm{SO}_{4}(11 \mathrm{ppt})$ and $\mathrm{SO}_{2}(7 \mathrm{ppt})$, respectively. Solid diamonds denote origin from aerosol, while open diamonds denote origin from gas, run using profile 1 . Solid squares denote origin from aerosol, while open squares denote origin from gas, run using profile 2. Plus signs denote origin from aerosol, and dotted line denotes origin from gas, experimental DECAFE data.

aerosol case, the reduction of scavenging efficiency with increasing $\mathrm{LWCg}$ and (2) in aerosol or gas cases; the dilution effect during the last part of a rain event due to depletion of the compounds initially present in the atmosphere and the strong influence on the ground rain concentrations of the vertical distribution of atmospheric species and of the vertical development of clouds. Exponential profiles (originating from ground level emissions) favor the dilution effect, whereas the advection of enriched air aloft leads to a smaller dilution coefficient.

This study allowed us to confirm and to characterize the influence of physical parameters (LWC $\mathrm{g}$ and $R$ ) of convective precipitating clouds on the rain chemical concentrations. If for any reason, it is possible to hypothesize reasonably on origin (local or advected) and atmospheric phase (gas or aerosol) of the removed species, then the retrieval of the atmospheric concentrations from rainfall and chemical data is possible using a relationship such as the nonlinear one derived in section 5 .

Acknowledgments. The DECAFE experiment is supported by the action Phase Atmospherique des Grands Cycles Biogéniques of the Programme Environnement/CNRS. The authors express their gratitude to E. C. Nickerson for his helpful comments.

\section{References}

Andreae, M. O., R. W. Talbot, T. W. Andreae, and R. C. Harris, Formic and acetic acid over the central amazon region, Brazil, A dry season, J. Geophys. Res., 93, 1616-1624, 1988.

Andreae, M. O., H. Berresheim, H. Bingemer, D. J. Jacob, B. L. Lewis, S. M. Li, and R. W. Talbot, The atmospheric sulfur cycle over the Amazon Basin, 2, Wet season, J. Geophys. Res., 95, $16,813-16,824,1990$ a.

Andreae, M. O., R. W. Talbot, H. Berresheim, and K. M. Beecher, Precipitation chemistry in central Amazonia, J. Geophys. Res., 95, 16,987-16,999, 1990b.

Andreae, M. O., A. Chapuis, B. Cros, J. Fontan, G. Helas, C. Justice, Y. J. Kaufman, A. Minga, and D. Nganga, Ozone and Aitken nuclei over equatorial Africa: Airborne observation during DECAFE 88, J. Geophys. Res., 97, 6137-6148, 1992.

Bingemer, H. G., M. O. Andreae, T. W. Andreae, P. Artaxo, G. Helas, D. J. Jacob, N. Mihalopoulos, and B. C. Nguyen, Sulfur gases and aerosols in and above the equatorial african rain forest, J. Geophys. Res., 97, 6207-6217, 1992.

Brimblecombe, P., and G. A. Dawson, Wet removal of highly soluble gases, J. Atmos. Chem., 2, 95-107, 1984.

Calvert, J. G., A. Lazrus, G. Kok, B. Heikes, J. Walega, J. Lind, and C. Cantrell, Chemical mechanisms of acid generation in the troposphere, Nature, 317, 27-35, 1985.

Campistron, B., G. Despaux, and J. P. Lacaux, A microcomputer data acquisition system for real-time processing of raindrop size distribution measured with the RD69 disdrometer, J. Atmos. Oceanic Technol., 4, 536-540, 1987.

Chameides, W. L., and D. D. Davis, The free radical chemistry of cloud droplets and its impact upon the composition of rain, $J$. Geophys. Res., 87, 4863-4877, 1982.

Cros, B., R. A. Delmas, D. Nganga, and B. Clairac, Seasonal trends of ozone in equatorial Africa: Experimental evidence of photochemical formation, J. Geophys. Res., 93, 8355-8366, 1988.

Cros, B., D. Nganga, R. A. Delmas, and J. Fontan, Tropospheric ozone and biomass burning in intertropical Africa, in Global Biomass Burning, edited by J. Levine, pp. 141-146, MIT Press, Cambridge, Mass., 1991.

Flossman, A. I., H. R. Pruppacher, and J. H. Topallian, A theorical study of the wet removal of atmospheric pollutants, Part II, The uptake and reistribution of (NH4)2SO4 particles and $\mathrm{SO}_{2}$ gas simultaneously scavenged by growing clouds drops, J. Atmos. Sci., 44, 2912-2923, 1987. 
Fontan, J., A. Druilhet, B. Benech, and R. Lira, The DECAFE experiments: Overview and meteorology, J. Geophys. Res., 97, 6123-6136, 1992.

Garstang, M., S. Ulanski, S. Greco, J. Scala, R. Swap, D. Fitzjarrald, D. Martin, E. Browell, M. Shipman, V. Connors, R. Harris, and R. Talbot, The Amazon boundary-layer experiment (ABLE 2B): A meteorological perspective, Bull. Am. Meteorol. Soc., 71(1), 1990.

Helas, G., H. Bingemer, and M. O. Andreae, Organic acids over equatorial Africa: Results from DECAFE 88, J. Geophys. Res., 97, 6187-6193, 1992.

Junge, C. E., Air Chemistry and Radioactivity, Int. Geophys. Ser., vol. 4, 382 pp., Academic, San Diego, Calif., 1963.

Kessler, E., On the redistribution and continuity of water substance in atmospheric circulations, Meteorol. Monogr., 10(32), 84 pp., 1969.

Kirchhoff, V. W. J. H., I. M. O. Da Silva, and E. V. Browell, Ozone measurements in Amazonia: Dry season versus wet season, $J$. Geophys. Res., 95, 16,913-16,926, 1990.

Lacaux, J. P., and J. A. Warburton, The deposition of silver released from Soviet Oblako rockets in precipitation during the hail suppression experiment, Grssversuch IV, 1, Measurements of background and a preliminary seeding test, J. Appl. Meteorol., 19, 771-778, 1980.

Lacaux, J. P., R. Delmas, B. Cros, B. Lefeivre, and M. O. Andreae, Influence of biomass buming emissions on precipitation chemistry in the equatorial forests of Africa, in Global Biomass Burning, edited by J. Levine, 161-173 pp., MIT Press, Cambridge, Mass., 1991.

Lacaux, J. P., R. Delmas, G. Kouadio, B. Cros, and M. O. Andreae, Precipitation chemistry in the Mayombe forest of Equatorial Africa, J. Geophys. Res., 97, 6195-6206, 1992a

Lacaux, J. P., J. Loemba-Ndembi, B. Lefeivre, B. Cros, and R. Delmas, Biogenic emissions and biomass buming influences of the chemistry of the fogwater and stratiform precipitations in the african equatorial forest, Atmos. Environ. 26A, 541-551, $1992 \mathrm{~b}$.

Lefeivre, B., Etude exérimentale et par modélisation des caractéristiques physiques et chimiques des précipitatons collectées en forêt equatoriale Africaine, Thèse de doctorat, Université de Paul Sabatier, 308 pp., Toulouse, France, 1993.

Lelieveld, J., and P. Crutzen, Influence of cloud photochemical processes on tropospheric ozone, Nature, 343, 227-233, 1990.

Lin Xing, and W. L. Chameides, Model simulation of rainout and washout from a warm stratiform cloud, J. Atmos. Chem., 10, $1-20,1990$.

Liu, J. Y., and H. D. Orville, Numerical modeling of precipitation and cloud shadow effects on mountain induced cumuli, J. Atmos. Sci., 26, 1283-1299, 1969.

Marenco, A., J. C. Medale, and S. Prieur, Study of tropospheric ozone in the tropical belt (Africa, America) from STRATOZ and TROPOZ campaigns, Atmos. Environ., 24(11), 2823-2834, 1990.

Marshall, J. S., and W. M. Palmer, The distribution of raindrops with size, J. Meteorol., 5, 165-166, 1948.

Orville, H. D., and F. J. Kopp, Numerical simulation of the life history of a hailstorm, J. Atmos. Sci., 34, 1596-1618, 1977.

Pandis, S. N., and J. H. Seinfeld, Sensitivity analysis of a chemical mechanism for aqueous phase atmospheric chemistry, J. Geophys. Res., 94, 1105-1126, 1989.

Rudolph, J., A. Khedim, and B. Bonsang, Light hydrocarbons in the tropospheric boundary layer over tropical Africa, J. Geophys. Res., 97, 6181-6186, 1992.

Ruthledge, S. A., D. A. Hegg, and P. V. Hobbs, A numerical model for sulfur and nitrogen scavenging in narrow cold-frontal rainbands, Part I, Model description and discussion of microphysical fields, J. Geophys. Res., 91, 14,385-14,402, 1986.

Schmit, T. J., K. F. Brueske, W. L. Smith, and W. P. Menzel, Visible and infrared spin scan radiometer atmospheric sounder water vapor and wind fields over Amazonia, J. Geophys. Res., 95, $17,031-17,038,1990$.

Seinfeld, J. H., Atmospheric Chemistry and Physics of Air Polution, 738 pp., John Wiley, New York, 1986.

Taylor, G. R., Sulfate production and deposition in midlatitude continental cumulus clouds, Part II, Chemistry model formulation and sensitivity analysis, J. Atmos. Sci., 46, 1991-2007, 1989.

Tremblay, A., Cumulus cloud transport, scavenging, and chemistry: Observations and simulations, Atmos. Environ., 21(11), 2345$2364,1987$.

S. Cautenet, LAMP, Centre National de la Recherche Scientifique, URA 267, Université Blaise Pascal, Clermont, Ferrand, 63000 , France.

B. Lefeivre, CRA, Centre National de la Recherche Scientifique, URA 354, Lannemezan, 65300, France.

(Received April 23, 1993; revised August 6, 1993; accepted September 22, 1993.) 